Jurnal Akuntansi \& Perpajakan, Volume 2, No. 2, Januari 2021

\title{
ANALISIS PENGARUH KINERJA PERBANKAN TERHADAP HARGA SAHAM (STUDI EMPIRIS PADA INDUSTRI PERBANKAN YANG TERDAFTAR DIBURSA EFEK INDONESIA \\ PADA TAHUN 2012 - 2015) \\ Eric Alfretdo ${ }^{1}$, Fakhruddin Nasution ${ }^{2}$ \\ Sekolah Tinggi Ilmu Ekonomi Jayakarta \\ 1) eric@ stie.jayakarta.ac.id ${ }^{2)}$ fhdnst@yahoo.co.id
}

\begin{abstract}
This study was conducted to Analyze the Influence of CAR, NIM, LDR, NPL and BOPO to Stock Prices in the banking industrial were listed on Indonesia Stock Exchange in the period 2012-2015. The sampling technique used was purposive sampling method to obtain 20 banking companies. This study uses the hypothesis test analysis model of multiple linear regression analysis (Multiple Linear Regression). The results of this study showed that the CAR dosen't have an effect to Stock Prices. While LDR and NIM have a positive effect to stock prices. NPL and BOPO has a negative effect to Stock Prices.
\end{abstract}

Keywords: $C A R, N I M, L D R, N P L, B O P O$, and Stock Price

\section{ABSTRAK}

Penelitian ini dilakukan untuk Menganalisis Pengaruh CAR, NIM, LDR, NPL dan BOPO terhadap Harga Saham pada industri perbankan yang terdaftar di Bursa Efek Indonesia periode 2012-2015. Teknik pengambilan sampel yang digunakan adalah metode purposive sampling sehingga diperoleh 20 perusahaan perbankan. Penelitian ini menggunakan model analisis uji hipotesis analisis regresi linier berganda (Regresi Linier Berganda). Hasil penelitian ini menunjukkan bahwa CAR tidak berpengaruh terhadap Harga Saham. Sedangkan LDR dan NIM berpengaruh positif terhadap harga saham. NPL dan BOPO berpengaruh negatif terhadap Harga Saham.

Kata-kata Kunci: CAR, NIM, LDR, NPL, BOPO, dan Harga Saham

\section{PENDAHULUAN}

Tahun 2015 merupakan tahun yang penuh tantangan bagi perekonomian Indonesia. Kondisi perekonomian diliputi gejolak, baik yang bersumber dari global maupun dalam negeri. Pemulihan ekonomi dunia yang masih lemah, berlanjutnya penurunan harga komoditas dan menurunnya aliran modal asing ke negara berkembang menjadi pemicu tekanan terhadap perekonomian negara berkembang termasuk Indonesia. Dari sisi dalam negeri, tingginya tekanan terhadap nilai tukar Rupiah, kinerja ekspor yang menurun sebagai dampak perekonomian global, dan belum optimalnya 
Jurnal Akuntansi \& Perpajakan, Volume 2, No. 2, Januari 2021

penyerapan anggaran fiskal mewarnai dinamika perekonomian Indonesia.

Kondisi tersebut tergambarkan dari Indeks Harga Saham Gabungan (IHSG) mengalami penurunan yang signifikan termasuk perusahaan yang bergerak dalam bidang perbankan. Namun hal ini berbanding terbalik dengan laporan Bank Indonesia dimana bank indonesia mencatat bahwa kinerja bank-bank besar di indonesia rata-rata mengalami kenaikan. Hal ini salah satunya dapat dilihat dari rata-rata laba bersih bank di indonesia yang terdaftar di Bursa Efek Indonesia mengalami kenaikan.

Pada tahun 2015 harga saham pada bankbank yang terdaftar di Bursa Efek Indonesia mengalami penurunan yang cukup signifikan. Padahal jika di lihat dari laporan keuangan bank, laba bersih yang diperoleh bank-bank yang terdaftar di Bursa Efek Indonesia rata-rata mengalami kenaikan. Bank memiliki beberapa rasio yang berbeda dengan perusahaan pada umumnya, analisa rasio keuangan bank telah diatur dalam Peraturan Bank Indonesia Nomor 13/1/PBI/2011 tentang penilaian tingkat kesehatan bank umum dimana peraturan tersebut juga menjadi referensi dibuatnya Surat Edaran nomor 13/24/DPNP/2011 perihal penilaian tingkat kesehatan bank umum.

Dalam menjalankan peran dan fungsinya bank juga berkewajiban untuk membuat laporan keuangan. Laporan keuangan entitas atau bank go public yang dipublikasikan merupakan salah satu sumber informasi yang sering digunakan oleh para investor untuk mengambil keputusan. Tujuan laporan keuangan adalah memberikan informasi mengenai posisi keuangan, kinerja keuangan, dan arus kas entitas yang bermanfaat bagi sebagian besar kalangan pengguna laporan keuangan dalam pembuatan keputusan ekonomi serta menunjukkan pertanggung jawaban manajemen atas penggunaan sumber-sumber daya yang dipercayakan kepada mereka.

Harga saham merupakan salah satu faktor yang memotivasi investor berinvestasi dan juga merupakan suatu imbalan atas keberanian investor dalam menanggung resiko atas investasi yang dilakukannya. Perubahan harga saham di bursa dipengaruhi oleh kesepakatan harga antara penjual dan pembeli. Kualitas saham atau kinerja keuangan perusahaan adalah hal yang menentukan berapa nilai saham tersebut akan dijual atau akan dibeli. Investor mengetahui informasi seputar saham yang akan dibeli adalah melalui data yang ada di dalam laporan keuangan. Kemudian untuk dapat mengetahui informasi mengenai harga saham perusahaan lebih spesifik adalah dengan melakukan analisis rasio keuangan. Dari perhitungan rasio-rasio inilah investor kemudian dapat memutuskan apakah saham tersebut layak untuk dibeli atau dijual.

Beberapa penelitian yang memiliki keterkaitan dengan dengan harga saham dan rasio-rasio keuangan telah dilakukan, 
Jurnal Akuntansi \& Perpajakan, Volume 2, No. 2, Januari 2021

diantaranya Indra dan Hatta (2015) tentang pengaruh kinerja keuangan terhadap harga saham 10 bank terkemuka di Indonesia menunjukkan variabel LDR, CAR, dan ROE terhadap harga saham secara parsial berpengaruh signifikan, kemudian NPL tidak berpengaruh terhadap harga saham.

Sigit (2013) tentang pengaruh NPL, LDR, ROA, ROE, NIM, BOPO, dan CAR terhadap harga saham pada sub sektor perbankan yang terdaftar di bursa efek Indonesia tahun 20082012 menunjukkan bahwa variabel NPL, LDR, ROA, NIM, BOPO, dan CAR berpengaruh secara signifikan terhadap harga saham.

Setyaningsih (2005) menganalisa pengaruh rasio keuangan terhadap harga saham pada perusahaan perbankan di Bursa Efek Indonesia. Hasil dari penelitian ini menunjukkan bahwa LDR berpengaruh negatif terhadap perubahan harga saham, artinya dengan peningkatan LDR memberikan indikasi semakin rendahnya kemampuan likuiditas bank yang bersangkutan yang berakibat pada penurunan harga saham. Sedangkan untuk CAR, NPM, dan EPS berpengaruh positif terhadap perubahan harga saham.

Perbedaan antara penelitian terdahulu dengan penelitian ini adalah pada periode penelitian yang dilakukan. Penelitian ini memiliki periode penelitian selama 4 tahun, dimana selama periode penelitian perekonomian di Indonesia masih dalam kondisi kurang baik.
Dari kondisi tersebut penelitian ini ingin kembali mengkaji lebih lanjut mengenai pengaruh CAR, NIM, LDR, NPL dan BOPO terhadap Harga Saham. Dari uraian diatas maka penulis tertarik untuk melakukan penelitian lebih lanjut tentang Analisis Pengaruh Capital Adequacy

Ratio (CAR), Net Interest Margin (NIM), Loan to Deposit Ratio (LDR), Net Performing Loan (NPL), dan Beban Operasional dan Pendapatan Operasional (BOPO) terhadap Harga Saham pada Industri Perbankan yang Terdaftar di Bursa Efek Indonesia".

Berdasarkan uraian pada latar belakang di atas, maka dapat dikemukakan permasalahan penelitian yang terjadi yaitu pada periode penelitian yang dilakukan. Penelitian ini memiliki periode penelitian selama 4 tahun, dimana selama periode penelitian perekonomian di Indonesia masih dalam kondisi kurang baik, maka penelitan ini akan menguji kembali mengenai kineja perbankan yaitu, rasio capital adequacy ratio (CAR), loan to deposit ratio (LDR), net interest margin (NIM), non performing loan (NPL) dan beban operasional pada pendapatan operasional (BOPO), terhadap harga saham perusahaan perbankan yang go public di Bursa Efek Indonesia (BEI).

Manfaat penelitian ini bagi investor dimana penelitian ini diharapkan dapat menjadi suatu bahan pertimbangan seorang investor dalam pengambilan keputusan untuk melakukan 
Jurnal Akuntansi \& Perpajakan, Volume 2, No. 2, Januari 2021

investasi khususnya investasi saham pada sektor perbankan. Kemudian bagi perusahaan penelitian ini diharapkan dapat memberikan masukan bagi perusahaan untuk dapat meningkatkan kinerja sehingga dapat meningkatkan harga saham ataupun imbalan sahamnya di pasar modal. Dan kemudian bagi peneliti dan pihak lain penelitian ini merupakan penerapan dari ilmu ekonomi khususnya manajemen keuangan yang telah didapat dari proses belajar penulis sehingga menambah wawasan penulis mengenai bagaimana penerapan teori dengan praktek yang sebenarnya. Penelitian ini juga diharapkan dapat menjadi masukan dan digunakan sebagai acuan penelitian lebih lanjut ataupun peneliti sejenis nantinya.

\section{KAJIAN LITERATUR}

Teori sinyal menjelaskan mengapa perusahaan mempunyai dorongan untuk memberikan informasi laporan keuangan pada pihak eksternal. Dorongan perusahaan untuk memberikan informasi karena terdapat asimetri informasi antara perusahaan dan pihak luar karena perusahaan mengetahui lebih banyak mengenai perusahaan dan prospek yang akan datang daripada pihak luar (investor, kreditor). Kurangnya informasi bagi pihak luar mengenai perusahaan menyebabkan mereka melindungi diri mereka dengan memberikan harga yang rendah untuk perusahaan. Perusahaan dapat meningkatkan nilai perusahaan dengan mengurangi informasi asimetri. Informasi asimetri dapat dikurangi dengan memberikan sinyal kepada pihak luar berupa informasi keuangan yang dapat dipercaya, sehingga mengurangi ketidakpastian prospek perusahaan di masa yang akan datang

Investasi adalah komitmen saat ini atas uang atau sumber daya lain dengan harapan untuk mendapatkan keuntungan di masa depan (Bodie et al, 2014). Menurut Samuelson (2004), investasi meliputi penambahan stok modal atau barang di suatu negara, seperti bangunan peralatan produksi, dan barang-barang

inventaris dalam waktu satu tahun. Tujuan utama investor dalam menanamkan dananya ke bursa efek yaitu untuk mencari pendapatan atau tingkat pengembalian investasi (return) baik berupa pendapatan dividen maupun pendapatan dari selisih harga jual saham terhadap harga belinya (capital gain).

Menurut Hartono (2014), terdapat beberapa alasan mengapa seseorang melakukan investasi, antara lain adalah untuk mendapatkan kehidupan yang lebih layak di masa yang akan datang. Seseorang yang bijaksana akan berpikir bagaimana meningkatkan taraf hidupnya dari waktu atau setidaknya berusaha bagaimana 
Jurnal Akuntansi \& Perpajakan, Volume 2, No. 2, Januari 2021

mempertahankan tingkat pendapatannya yang ada sekarang agar tidak berkurang di masa yang akan datang.

Menurut Hartono (2014), proses keputusan investasi terdiri dari penentuan tujuan investasi, penentuan kebijakan investasi, pemilihan strategi portofolio, pemilihan aset, pengukuran dan evaluasi kinerja portofolio. Berdasarkan definisi diatas, maka dapat disimpulkan bahwa proses keputusan investasi merupakan proses keputusan yang berkesinambungan (on going process). Artinya, jika tahap pengukuran dan evaluasi kinerja telah dilewati dan ternyata hasilnya kurang baik, maka proses keputusan investasi harus dimulai dari pertama, demikian seterusnya sampai dicapai keputusan investasi yang paling optimal.

Harga saham dapat didefinisikan sebagai persepsi investor terhadap nilai suatu perusahaan di masa yang akan dating. Persoalan mendasar bagi setiap investor di pasar modal adalah bagaimana menentukan harga saham yang seharusnya serta melakukan peramalan (forecasting) terhadap perubahan harga saham pada masa yang akan datang sehingga dapat dijadikan dasar untuk melakukan investasi. Ada beberapa konsep dasar nilai atau harga saham yang akan dibahas disini, yaitu nilai buku per lembar saham, harga pasar, harga teoritis/intrinsic value, dan harga nominal. Nilai buku per lembar saham adalah nilai kekayaan bersih ekonomis dibagi dengan jumlah lembar saham biasa yang beredar. Kekayaan bersih ekonomis merupakan selisih total aktiva dengan total kewajiban. Harga pasar adalah harga yang terbentuk di pasar jual beli saham. Harga teoritis adalah harga saham yang seharusnya terjadi, sedangkan harga nominal adalah harga yang tercantum pada saham biasa.

Valuasi adalah proses penilaian dan analisis suatu saham untuk mengetahui apakah suatu saham bagus dan masih murah. Saham bagus adalah saham yang memiliki prospek, sedangkan saham murah adalah saham yang harga pasarnya lebih rendah dari harga saham seharusnya (intrinsic value).

Tujuan dari Valuasi saham adalah untuk memberikan suatu gambaran pada manajemen atas estimasi nilai saham suatu perusahaan yang akan digunakan sebagai masukan kepada manajemen dalam mempertimbangkan kebijakan atas saham yang dimiliki perusahaan. Ada tiga jenis valuasi saham, yaitu:

a. Nilai Nominal (Nominal atau Par Value)

Nilai nominal merupakan besaran dari nilai yang tercantum dalam akte pendirian perusahaan. Nilai nominal dapat dihitung dengan cara membagi total modal disetor dengan jumlah saham yang diterbitkan. Dengan demikian besarnya nilai nominal merupakan kebijakan perusahaan, dimana nilai nominal dipengaruhi oleh modal disetor dan jumlah saham yang diterbitkan.

b. Nilai Buku (Book Value) 
Jurnal Akuntansi \& Perpajakan, Volume 2, No. 2, Januari 2021

Nilai buku adalah nilai yang berdasar pada total ekuitas perubahan yang tercatat di dalam laporan keuangan. Nilai buku saham dapat dihitung denan membagi total ekuitas dengan jumlah saham yang beredar. Total ekuitas sesuai dengan total nilai ekuitas yang tercantum di dalam neraca yang memiliki komponen antara lain:

1) Modal saham ditempatkan dan disetor

2) Agio/ disagio saham atau tambahan modal disetor

3) Cadangan-cadangan yang dibentuk untuk keperluan tertentu

4) Saham treasuri, yaitu saham beredar yang dibeli kembali

5) Pos-pos laba/ rugi lainnya

6) Saldo Laba/ Rugi

Jika komponen-komponen ekuitas tersebut mengalami perubahan, maka nilai buku saham akan mengalami perubahan dan faktor utama yang dapat mempengaruhi perubahan tersebut adalah saldo laba/ rugi. Dengan demikian, nilai saham sangat dipengaruhi oleh kinerja perusahaan khusus perolehan laba

c. Nilai atau Harga Pasar (Market Value)

Nilai atau Harga pasar adalah besarnya nilai/ harga yang bersedia untuk dibayarkan oleh investor atas satu lembar saham perusahaan yang dimiliki melalui transaksi jual beli di bursa. Besarnya nilai atau harga saham dipengaruhi dan ditentukan oleh kesediaan investor untuk membayar satu lembar suatu perusahaan.

Faktor yang mempengaruhi nilai atau harga saham tersebut adalah hal-hal yang mempengaruhi kesediaan investor tersebut. Seseorang bersedia membeli dan membayar saham dengan harga lebih tinggi, apabila investor mempunyai persepsi yang baik terhadap saham dengan harga lebih tinggi, apabila investor mempunyai persepsi yang baik terhadap saham yang akan dibeli tersebut. Artinya saham tersebut mampu memenuhi apa yang diharapkan dan dibutuhkan oleh investor dan tinggi atau rendahnya harga suatu saham dipengaruhi oleh persepsi investor.

Menurut Undang-undang Nomor 10 tahun 1998 tentang Perubahan atas Undang-undang nomor 7 Tahun 1992 tentang perbankan pasal 1 pengertian perbankan adalah segala sesuatu yang menyangkut tentang bank, mencakup kelembagaan, kegiatan usaha, serta cara dan proses dalam melaksanakan kegiatan usahanya. Bank sendiri merupakan badan usaha yang menghimpun dana dari masyarakat dalam bentuk simpanan dan menyalurkannya kepada masyarakat dalam bentuk kredit dan atau bentukbentuk lainnya dalam rangka meningkatkan taraf hidup rakyat banyak.

Fungsi utama perbankan indonesia menurut Undang-undang Nomor 7 tahun 1992 tentang perbankan sebagaimana telah diubah 
Jurnal Akuntansi \& Perpajakan, Volume 2, No. 2, Januari 2021

dengan Undang-undang Nomor 10 tahun 1998 adalah sebagai penghimpun dan penyalur dana milik masyarakat. Fungsi bank menurut Budisantoso dan Triandaru (2006) terbagi menjadi tiga bagian, yaitu:

1) Agent of Development

Kegiatan perekonomian masyarakat meliputi sektor moneter dan sektor riil, keduanya tidak dapat dipisahkan dan berinteraksi saling mempengaruhi. Tugas bank sebagai penghimpun dan penyalur dana diperlukan untuk kegiatan perekonomian di sektor riil. Kegiatan bank tersebut memungkinkan masyarakat melakukan kegiatan investasi, distribusi, serta konsumsi barang dan jasa.

2) Agent of Trust

Bank sebagai lembaga keuangan yang dasar utama kegiatannya adalah kepercayaan (trust) dari masyarakat, baik dalam penghimpunan dana maupun penyaluran dana. Masyarakat akan mau menyimpan uangnya di bank apabila dilandasi dengan adanya unsur percaya. Masyarakat percaya bahwa uang mereka yang ada di bank itu dalam kondisi yang aman atau tidak akan disalahgunakan, uang mereka akan dikelola dengan baik, bank tidak akan bangkrut, dan pada saat yang telah ditentukan simpanan tersebut dapat ditarik kembali dari bank.

3) Agent of Services

Selain kegiatan penghimpunan dan penyalur dana, bank juga memberikan bermacam-macam jasa yang ditawarkan kepada masyarakat, antara lain berupa jasa pengiriman uang, jasa penitipan barang berharga, jasa pemberian jaminan bank, dan jasa penyelesaian banyak, dan jasa penyelesaian tagihan.

Rasio kecukupan modal yang sering disebut dengan Capital Adequacy Ratio (CAR) mencerminkan kemampuan bank untuk menutupi risiko kerugian dari aktivitas yang dilakukannya dan kemampuan bank dalam mendanai kegiatan operasionalnya Idroes (2008). CAR memperlihatkan seberapa besar jumlah seluruh aktiva bank yang mengandung risiko (kredit, penyertaan, surat berharga, tagihan pada bank lain) ikut dibiayai dari modal sendiri disamping memperoleh dana-dana dari sumbersumber di luar bank Amilia dan Herdiningtyas (2005).

Setiap bank diwajibkan untuk memelihara rasio kecukupan modal atau CAR yang didasarkan pada ketentuan Bank For International Setlements yaitu sebesar $8 \%$ dari Aktiva Tertimbang Menurut Risiko (ATMR) Pandia (2010). Kecukupan modal yang dimiliki bank akan mempengaruhi besarnya nilai dana yang akan disalurkan kepada masyarakat, yang kemudian akan berpengaruh terhadap jumlah pendapatan bunga yang diperoleh perusahaan, semakin tinggi pendapatan bunga akan semakin tinggi laba bersih yang dihasilkan bank, dan nilai dividen akan naik juga sehingga harga saham akan mengalami kenaikan. 
Jurnal Akuntansi \& Perpajakan, Volume 2, No. 2, Januari 2021

Earning (rentabilitas) bank dinilai dengan rasio Net Interest Margin (NIM). Rasio NIM mencerminkan resiko pasar yang timbul akibat berubahnya kondisi pasar, dimana hal tersebut dapat merugikan bank Hasibuan (2007). Rasio NIM juga digunakan untuk mengukur kemampuan manajemen bank dalam menghasilkan pendapatan dari bunga dengan melihat kinerja bank dalam menyalurkan kredit, mengingat pendapatan operasional bank sangat tergantung dari selisih bunga dari kredit yang disalurkan Mahardian (2008).

Meningkatnya pendapatan bunga bersih atau dimana pihak perbankan mampu memperbesar spreed antara suku bunga kredit dengan suku bunga dana merupakan suatu peningkatan yang terjadi pada NIM bank tersebut, sehingga bank akan memperoleh tanggapan positif dari para investor, kemudian investor akan mempertimbangkan keputusan untuk berinvestasi pada bank tersebut dan kecenderungan investor akan memilih menempatkan investasinya dengan melihat kondisi perusahaan yang tidak bermasalah Chilla (2010). Perhitungan NIM terdiri dari :

a. Pendapatan bunga bersih diperoleh dari pendapatan pendapatan bunga dikurangi beban bunga.

b. Aktiva Produktif yang diperhitungkan adalah aktiva produktif yang menghasilkan bunga seperti penempatan pada bank lain, surat berharga, penyertaan, dan kredit yang diberikan.

Adapun penilaian rasio NIM memiliki batasan kategori sehat jika hasil rasionya lebih dari 1,5\% dan kategori tidak sehat jika hasil rasionya kurang dari 1,5\%. Semakin besar NIM suatu bank, maka semakin baik posisi bank tersebut sari sisi aset Dendawijaya (2009). Besarnya rasio ini dapat dilihat dari bagaimana kemampuan bank dalam memaksimalkan pengelolaan terhadap aktiva yang bersifat produktif untuk melihat seberapa besar perolehan pendapatan bunga bersih yang diperoleh. Semakin besar NIM yang dicapai oleh suatu bank maka akan meningkatkan pendapatan bunga atas aktiva produktif yang dikelola oleh bank yang bersangkutan, sehingga laba bank akan meningkat dan akann berpengaruh positif terhadap harga saham.

Loan to Deposit Ratio (LDR) adalah rasio keuangan perusahaan yang berhubungan dengan aspek likuiditas. Rasio ini digunakan untuk menilai likuiditas suatu bank dengan cara membagi jumlah kredit yang diberikan oleh bank terhadap dana yang diterima dari pihak ketiga. Kredit yang dimaksudkan adalah :

a. Kredit yang diberikan kepada masyarakat dikurangi dengan bagian kredit sindikasi yang dibiayai bank lain.

b. Penanaman pada bank lain dalam bentuk kredit yang diberikan dengan jangka waktu lebih dari 3 bulan. 
Jurnal Akuntansi \& Perpajakan, Volume 2, No. 2, Januari 2021

c. Penanaman pada bank lain, dalam bentuk kredit dalam rangka kredit sindikasi.

Berdasarkan ketentuan Bank Indonesia, besarnya standar nilai Loan to Deposit Ratio (LDR) menurut Bank Indonesia adalah antara $85 \%$ - 100\%. Dan LDR yang berlaku di Indonesia adalah maksimum 115\%. LDR merupakan perbandingan antara seluruh jumlah kredit atau pembayaran yang diberikan bank dengan dana yang diterima bank. Tujuan penting dari perhitungan LDR adalah untuk mengetahui serta menilai seberapa jauh bank memiliki kondisi sehat dalam menjalankan operasi atau kegiatan usahanya.

Penyaluran kredit merupakan kegiatan utama bank, oleh karena itu sumber pendapatan utama bank berasal dari kegiatan ini. Semakin besar penyaluran dana dalam bentuk kredit dibandingkan dengan deposit atau simpanan masyarakat pada suatu bank membawa konsekuensi semakin besarnya risiko yang harus ditanggung oleh bank yang bersangkutan. Semakin tinggi Loan to Deposit Ratio (LDR) maka laba perusahaan semakin meningkat dan nilai dividen akan semakin besar, semakin tinggi nilai dividen suatu perusahaan makan semakin tinggi harga saham atas perusahaann tersebut.

NPL merupakan salah satu indikator kesehatan kualitas asset bank. NPL merupakan rasio yang dipergunakan untuk mengukur kemampuan bank dalam meng-cover risiko kegagalan pengembalian kredit oleh debitur
Darmawan (2004). NPL mencerminkan risiko kredit, semakin kecil NPL semakin kecil pula risiko kredit yang ditanggung pihak bank. Ketentuan Bank Indonesia ialah bahwa bank harus menjaga NPL-nya dibawah 5\%, hal ini sejalan dengan ketentuan Bank Indonesia.

Apabila bank mampu menekan rasio NPL $5 \%$, maka potensi keuntungan yang akan diperoleh akan semakin besar, karena bank-bank akan menghemat uang yang diperlukan untuk membentuk cadangan kerugian kredit bermasalah atau Penyisihan Penghapusan Aktiva Produktif (PPAP). Rendahnya PPAP yang dibentuk oleh bank-bank akan berpengaruh positif pada profitabilitas yang akan semakin besar sehingga laba bersih perusahaan akan naik dan akan mempengaruhi nilai dividen. Nilai dividen mengalami kenaikan maka harga saham akan megalami kenaikan.

Rasio BOPO digunakan untuk mengukur tingkat efisiensi dan kemampuan bank dalam melakukan kegiatan operasinya. Biaya operasional merupakan biaya yang dikeluarkan oleh bank dalam rangka menjalankan aktivitas usaha utamanya seperti biaya bunga, biaya pemasaran, biaya tenaga kerja, dan biaya operasi lainnya. Sedangkan pendapatan operasi merupakan pendapatan utama bank yaitu pendapatan yang diperoleh dari penempatan dana dalam bentuk kredit dan pendapatan opersional lainnya Prasnanungraha (2007). 
Jurnal Akuntansi \& Perpajakan, Volume 2, No. 2, Januari 2021

Rumus perhitungan yang digunakan untuk menghitung rasio BOPO sebagai berikut :

Adapun penilaian rasio atas $\mathrm{BOPO}$ berdasarkan Surat Edaran Bank Indonesia No. 6/23/DPNP memberikan batasan kategori sehat jika hasil rasionya kurang dari 94\% dan kategori tidak sehat jika hasil rasionya lebih dari $94 \%$.

Semakin rendah rasio BOPO semakin baik kinerja manajemen bank tersebut, karena lebih efisien dalam menggunakan sumber daya yang ada di dalam perusahan tersebut. Maka semakin besar nilai BOPO yang dihasilkan maka semakin rendah nilai laba bersih dan akan berpengaruh terhadap penurunan dividen. Jika nilai dividen mengalami penurunan maka harga saham akan turun.

Penelitian ini menggunakan variabel independen rasio keuangan bank dimana rasio keuangan tersebut merupakan faktor-faktor yang berasal dari internal perbankan untuk mengukur pengaruhnya terhadap return saham. Diduga bahwa rasio capital adequacy ratio (CAR), loan to deposit ratio (LDR), net interest margin (NIM), beban operasional pada pendapatan operasional (BOPO) dan non performing loan (NPL), memiliki hubungan yang kuat terhadap harga saham perusahaan perbankan. Dengan demikian dapat dirumuskan kerangka pemikiran penelitian sebagai berikut:

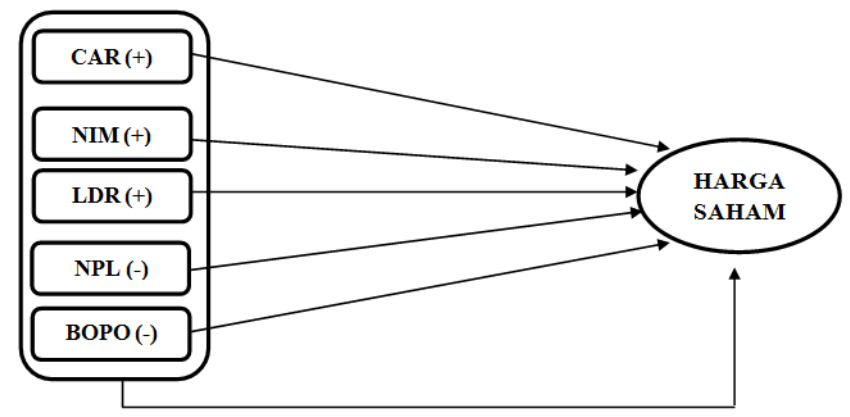

1) Pengaruh CAR terhadap Harga Saham Aspek Capital Adequacy Ratio (CAR) merupakan rasio perbandingan modal sendiri bank dengan kebutuhan modal yang tersedia setelah dihitung dengan margin risk (pertumbuhan resiko) dan aktiva tertimbang menurut resiko (ATMR). CAR dimaksudkan untuk dapat mengetahui kemampuan permodalan yang ada untuk menutup kemungkinan kerugian di dalam kegiatan perkreditan dan perdagangan suratsurat berharga.

Kecukupan modal yang dimiliki bank akan mempengaruhi besarnya nilai dana yang akan disalurkan kepada masyarakat, yang kemudian akan berpengaruh terhadap jumlah pendapatan bunga yang diperoleh perusahaan, semakin tinggi pendapatan bunga, akan semakin tinggi laba bersih yang dihasilkan bank, dan nilai dividen akan naik juga sehingga harga saham akan mengalami kenaikan.

Hal ini sesuai dengan penelitian yang dilakukan oleh Butarbutar (2014) dimana variabel CAR memiliki pengaruh yang 
Jurnal Akuntansi \& Perpajakan, Volume 2, No. 2, Januari 2021

positif terhadap harga saham. Sesuai dengan penelitian yang dilakukan oleh Wismaryanto (2013) dimana CAR berpengaruh positif terhadap harga saham. Berdasarkan penelitian yang dilakukan oleh Satria dan Hatta (2015) dimana CAR memiliki pengaruh yang positif terhadap perubahan harga saham. Berdasarkan pemaparan diatas maka dapat dirumuskan hipotesa sementara sebagai berikut :

Ha1: CAR berpengaruh positif terhadap Harga Saham

2) Pengaruh NIM terhadap Harga Saham Rasio Net Interest Margin (NIM) digunakan untuk mengukur kemampuan manajemen bank dalam mengelola aktiva produktifnya utntuk dapat menghasilkan pendapatan bunga bersih yang maksimal. Semakin besar rasio ini maka meningkatkan pendapatan bunga atas aktiva produktif yang dikelola bank sehingga kemungkinan suatu bank dalam kondisi bermasalah semakin kecil.

Semakin besar NIM yang dicapai oleh suatu bank maka akan meningkatkan pendapatan bunga atas aktiva produktif yang dikelola oleh bank yang bersangkutan, sehingga laba bank akan meningkat dan akann berpengaruh positif terhadap harga saham. Hal ini sesuai dengan penelitian yang dilakukan oleh Domiyanti (2012) dimana variabel NIM memiliki pengaruh yang positif terhadap harga saham. Berdasarkan uraian diatas maka dapat dirumuskan hipotesis sebagai berikut :

Ha2 : NIM berpengaruh positif terhadap Harga Saham

3) Pengaruh LDR terhadap Harga Saham Loan to Deposit Ratio (LDR) digunakan untuk menilai likuiditas suatu bank, yaitu dengan menunjukkan kemampuan suatu bank dalam menyediakan dana kepada debiturnya dengan modal yang dimiliki oleh bank maupun dana yang dikumpulkan dari masyarakat. Menurut Bank Indonesia, penilaian aspek likuiditas mencerminkan kemampuan bank untuk mengelola tingkat likuiditas yang memadai guna memenuhi kewajibannya secara tepat waktu dan untuk memenuhi kebutuhan yang lain. Disamping itu bank juga harus dapat menjamin kegiatan dikelola secara efisien dalam arti bahwa bank dapat menekan biaya pengelolaan likuiditas yang tinggi serta setiap saat bank dapat melikuidasi assetnya secara cepat dengan kerugian yang minimal.

Semakin besar penyaluran dana dalam bentuk kredit dibandingkan dengan deposit atau simpanan masyarakat pada suatu bank membawa konsekuensi semakin besarnya risiko yang harus ditanggung oleh bank yang bersangkutan. Semakin tinggi Loan to Deposit Ratio (LDR) maka laba perusahaan 
Jurnal Akuntansi \& Perpajakan, Volume 2, No. 2, Januari 2021

semakin meningkat dan nilai dividen akan semakin besar, semakin tinggi nilai dividen suatu perusahaan makan semakin tinggi harga saham atas perusahaann tersebut. Hal ini sesuai dengan penelitian yang dilakukan oleh Butarbutar (2014) dimana variabel LDR memiliki pengaruh yang signifikan terhadap harga saham. Sesuai dengan penelitian yang dilakukan oleh Wismaryanto (2013) dimana LDR berpengaruh positif terhadap harga saham. Berdasarkan penelitian yang dilakukan oleh Satria dan Hatta (2015) dimana LDR memiliki pengaruh yang positif terhadap perubahan harga saham. Berdasarkan uraian diatas maka dapat dirumuskan hipotesis sebagai berikut :

Ha3 : LDR berpengaruh positif terhadap Harga Saham

4) Pengaruh NPL terhadap Harga Saham Non Performing Loan (NPL) menunjukkan bahwa kemampuan manajemen bank dalam mengelola kredit bermasalah yang diberikan oleh bank. Semakin tinggi rasio ini maka akan semakin buruk kualitas kredit bank yang menyebabkan jumlah kredit bermasalah semakin besar, maka kemungkinan suatu bank dalam kondisi bermasalah semakin besar. Berdasarkan Peraturan Bank Indonesia Nomor 06/9/PBI/2004 yang dimaksud dengan Non
Performing Loan (NPL) adalah kredit dengan kualitas kurang lancar, diragukan, dan macet berdasarkan ketentuan Bank Indonesia.

Bank dalam memberikan kredit harus melakukan analisis terhadap kemampuan debitur untuk membayar kembali kewajibannya. Bank melakukan peninjauan, penilaian, dan pengikatan terhadap agunan untuk memperkecil risiko kredit Ali (2004). Apabila bank mampu menekan rasio NPL $5 \%$, maka potensi keuntungan yang akan diperoleh akan semakin besar, karena bankbank akan menghemat uang yang diperlukan untuk membentuk cadangan kerugian kredit bermasalah atau Penyisihan Penghapusan Aktiva Produktif (PPAP). Rendahnya PPAP yang dibentuk oleh bank-bank akan berpengaruh positif pada profitabilitas yang akan semakin besar sehingga laba bersih perusahaan akan naik dan akan mempengaruhi nilai dividen. Nilai dividen mengalami kenaikan maka harga saham akan megalami kenaikan.

Hal ini sesuai dengan penelitian yang dilakukan oleh Butarbutar (2014) dimana variabel NPL memiliki pengaruh yang signifikan terhadap perubahan harga saham. Dan sesuai dengan penelitan yang dilakukan oleh Muharam dan Haryanto (2015) dimana NPL memiliki pengaruh negatif terhadap harga saham. Berdasarkan uraian diatas 
Jurnal Akuntansi \& Perpajakan, Volume 2, No. 2, Januari 2021

maka dapat dirumuskan hipotesis sebagai berikut:

Ha4 : NPL berpengaruh negatif terhadap Harga Saham

5) Pengaruh BOPO terhadap Harga Saham Rasio Biaya Operasional dan Pendapatan Operasional (BOPO) sering disebut sebagai rasio efesiensi yang digunakan untuk mengukur kemampuan manajemen bank dalam mengendalikan biaya operasional dan pendapatan operasional yang dikeluarkan oleh perusahaan.

Semakin rendah rasio BOPO berarti semakin baik kinerja manajemen bank tersebut, karena lebih efisien dalam menggunakan sumber daya yang ada di dalam perusahan tersebut. Semakin besar nilai BOPO yang dihasilkan maka semakin rendah nilai laba bersih dan akan berpengaruh terhadap penurunan dividen. Jika nilai dividen mengalami penurunan maka harga saham akan turun. Hal ini sesuai dengan penelitan yang dilakukan oleh Muharam dan Haryanto (2015) dimana BOPO memiliki pengaruh negatif terhadap harga saham. Berdasarkan uraian diatas maka dapat dirumuskan hipotesis sebagai berikut:

Ha5 : BOPO berpengaruh negatif terhadap Harga Saham

\section{METODE PENELITIAN}

Sifat penelitian ini adalah metode penelitian deskriptif kuantitatif. Metode deskriptif adalah metode penelitian yang berpusat pada masalah-masalah atau fenomena yang bersifat aktual pada saat penelitian dilakukan. Sumber data yang digunakan adalah data sekunder. Data variabel bebas diperoleh dari laporan kinerja tahunan bank yang dipublikasikan.

Dalam penelitian ini variabel independen yang digunakan adalah Capital Adequacy Ratio (CAR), Net Interest Margin (NIM), Loan to Deposit Ratio (LDR), Non Performing Loan (NPL) dan Beban Operasional pada Pendapatan Operasional (BOPO) sebagai variabel dependen adalah Harga Saham yang Terdaftar di Bursa Efek Indonesia pada Tahun 2012-2015.

a. Harga Saham

$$
\text { CAR }=\frac{\text { Modal bank }(\text { Modal Inti }+ \text { Modal Pelengkap })}{\text { ATMR }(\text { Aktiva Tertimbang Menurut Resiko })} \times 100 \%
$$

b. Capital Adequancy Ratio (CAR)

Perhitungan untuk Capital Adequancy Ratio (CAR) menggunakan rumus sebagai berikut:

$C A R=\frac{\text { Modal bank }(\text { Modal Inti }+ \text { Modal Pelengkap })}{\text { ATMR }(\text { Aktiva Tertimbang Menurut Resiko })} \times 100 \%$

c. Net Interest Margin (NIM)

Perhitungan untuk Net Interest Margin (NIM) menggunakan rumus sebagai berikut: 
Jurnal Akuntansi \& Perpajakan, Volume 2, No. 2, Januari 2021

NIM $=\frac{\text { Pendapatan Bunga Bersih }}{\text { Rata-rata Total Aset Produktif }} \times 100 \%$

d. Loan to Deposit Ratio (LDR)

Perhitungan untuk Loan to Deposit Ratio (LDR) menggunakan rumus sebagai berikut:

$$
L D R=\frac{\text { Total Kredit }}{\text { Total dan Pihak Ketiga }} \times 100 \%
$$

e. Non Performing Loan (NPL)

Perhitungan untuk Non Performing Loan (NPL) menggunakan rumus sebagai berikut:

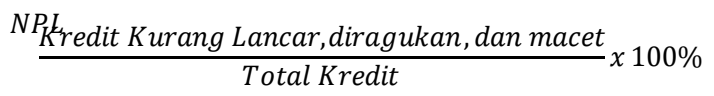

f. Beban Operasional dengan Pendapatan Operasional (BOPO)

Perhitungan untuk Beban Operasional dengan Pendapatan Operasional (BOPO) menggunakan rumus sebagai berikut:

$$
\text { BOPO }=\frac{\text { Biaya Operasional }}{\text { Pendapatan Operasional }} \times 100 \%
$$

\section{Metode Analisis Data}

Penelitian ini bertujuan untuk mengetahui pengaruh variabel independen terhadap dependen. Untuk melakukan hal tersebut menggunakan model regresi berganda.

Dimana :

Y : Harga Saham

b : Nilai Koefisien Regresi

: Nilai Konstanta
CAR : Capital Adequacy Ratio NIM : Net Interest Margin LDR : Loan of Deposit Ratio NPL : Non Performing Loan

BOPO : Biaya Operasional dan Pendapatan Operasional

\section{Uji Normalitas}

Salah satu persyaratan agar suatu model regresi menghasil model yang baik adalah data yang digunakan harus memiliki distribusi normal. Artinya data yang bersangkutan memiliki sebaran yang nilainya memusat pada nilai rata-rata (mean). Uji normalitas data dalam penelitian dilakukan secara grafis atau scatterplot sebaran dari nilai residual.

\section{Uji Asumsi Klasik}

a. Uji Multikolineritas

Uji multikolinieritas dimaksudkan untuk mengetahui apakah suatu model regresi yang dihasilkan terbebas dari gejala korelasi yang tinggi (sempurna) antara variabel bebasnya Gujarati (2010). Model regresi yang baik adalah model regresi yang tidak terdapat korelasi yang tinggi atau sempurna diantara variabel bebasnya. Untuk mengetahui suatu model terbebas dari gejala multikolenieritas dapat dilakukan nilai Tolerance dan VIF (Variance Inflation Factor) dari model yang dihasilkan. Suatu model regresi terbebas dari gejala multikolinieritas, jika nilai tolerance lebih besar dari 0,10 dan nilai VIF lebih kecil 
Jurnal Akuntansi \& Perpajakan, Volume 2, No. 2, Januari 2021

10 dari masing-masing variabel bebas yang membentuk model regresi.

b. Uji Heteroskedastisitas

Uji heteroskedastisitas dimaksudkan untuk mengetahui apakah terdapat ketidaksamaan varians dari setiap kesalahan acak (error) dari suatu model regresi yang dihasilkan Gujarati (2010). Model regresi yang baik adalah model yang terbebas gejalaa heteroskedastisitas atau model di mana varians dari setiap error bersifat homogen. Uji heteroskedastisitas dapat dilakukan dengan cara memperhatikan bagaimana pola sebaran (scatterplot) dari residual atau menggunakan uji Glejser, yaitu meregres nilai variabel bebas model terhadap nilai absolut residual model. Adapun hipotesis yang akan diuji adalah sebagai berikut: H0: Tidak terdapat gejala Heteroskedastisitas.

H1: Terdapat gejala Heteroskedastisitas.

Dasar pengambilan keputusan uji heteroskedastisitas menggunakan grafis sebagai berikut:

1) Jika titik menyebar dan tidak membentuk pola tertentu, maka model regresi yang dihasilkan diasumsikan terbebas dari gejala heteroskedastisitas atau hipotesis $\mathrm{HO}$ diterima dan $\mathrm{H} 1$ ditolak.

2) Jika titik tidak menyebar dan membentuk pola tertentu, maka model regresi yang dihasilkan diasumsikan tidak terbebas dari gejala heteroskedastisitas atau hipotesis $\mathrm{H} 0$ ditolak dan $\mathrm{H} 1$ diterima.

\section{c. Uji Autokorelasi}

Uji autokorelasi untuk menguji apakah dalam model regresi dihasilkan terjadi korelasi antara kesalahan ganguan (error) periode saat ini dengan kesalahan gangguan (error) periode sebelumnya Gujarati (2010). Autokorelasi muncul karena observasi yang berurutan sepanjang waktu berkaitan satu sama lain. Masalah yang timbul karena residual tidak bebas dari satu observasi ke observasi lainnya. Model regresi yang baik adalah model yang terbebas dari gejala autokorelasi antar-error.

Dalam penelitian uji autokorelasi dilakukan dengan Durbin-Watson Test (D-W Test) dengan hipotesis sebagai berikut:

H0: Tidak terdapat gejala autokorelasi.

H1: Terdapat gejala autokorelasi.

\section{Kriteria Autokorelasi Durbin-Watson}

\begin{tabular}{|l|l|l|}
\hline Hipotesis nol & Keputusan & Jika \\
\hline \hline Tidak ada autokorelasi positif & Tolak & $0<\mathrm{d}<\mathrm{dl}$ \\
\hline Tidak ada autokorelasi positif & $\begin{array}{l}\text { Tidak Ada } \\
\text { Keputusan }\end{array}$ & $\mathrm{dl} \leq \mathrm{d} \leq \mathrm{du}$ \\
\hline Tidak ada autokorelasi negative & Tolak & $4-\mathrm{dl}<\mathrm{d}<4$ \\
\hline Tidak ada autokorelasi negative & $\begin{array}{l}\text { Tidak Ada } \\
\text { Keputusan }\end{array}$ & $\begin{array}{l}4-\mathrm{du} \leq \mathrm{d} \leq 4 \\
-\mathrm{dl}\end{array}$ \\
\hline $\begin{array}{l}\text { Tidak ada autokorelasi, positifatau } \\
\text { negative }\end{array}$ & Tidak Tolak & $\begin{array}{l}\mathrm{du}<\mathrm{d}<4- \\
\mathrm{du}\end{array}$ \\
\hline
\end{tabular}

\section{Pengujian Hipotesis}

Dari uji sifat data penelitian diperoleh hasil bahwa data penelitian yang akan digunakan untuk membentuk model pengujian hipotesis sudah bersifat normal. Uji asumsi klasik (uji 
Jurnal Akuntansi \& Perpajakan, Volume 2, No. 2, Januari 2021

multikolinieritas, uji heteroskedastisitas, dan uji autokorelasi) ditemukan hasil bahwa model yang dihasilkan memenuhi persyaratan asumsi klasik yaitu terbebas dari gejala adanya mutikolinieritas, heteroskedastisitas, dan auokorelasi. Oleh karena model yang akan dibentuk sudah memenuhi syarat persamaan regresi ganda, maka selanjutnya dilakukan uji hipotesis sebagai berikut:

a. Uji Ketepatan Model (Goodness of Fit)

Uji ketepatan model (Goodness of fit) adalah pengujian yang dilakukan untuk mengetahui seberapa besar variabel bebas mampu menjelaskan perubahan atau variasi dari variabel terikat Gujarati (2010). Untuk mengetahui ketepatan suatu model digunakan parameter statistik yaitu koefisien determinasi (R2).

Nilai koefisien $=\frac{E S S}{T \Phi g t e r m i n a s i}=\frac{\sum e i^{2}}{\sum x \mathrm{~d}^{2} \text { lah }}$ antara 0 dan 1. Nilai R2 yang kecil berarti kemampuan variabel-variabel independen dalam menjelaskan variasi variabel dependen amat terbatas. Nilai yang mendekati 1 (satu) berarti variabel-variabel independen memberikan hampir semua informasi yang dibutuhkan untuk memprediksi variasi variabel dependen.

b. Uji Pengaruh Variabel Bebas Secara Simultan (Uji F)

Uji pengaruh variabel bebas secara simultan dilakukan untuk mengetahui sejauhmana pengaruh variabel bebas secara bersama-sama (simultan) terhadap variabel terikat. Untuk mengetahui bagaimana pengaruh variabel bebas secara bersama-sama (simultan) terhadap variabel terikat menggunakan uji $\mathrm{F}$. Uji ini dilakukan dengan ketentuan sebagai berikut Ghozali (2016):

1) Merumuskan Hipotesis (Ha)

Ha diterima : berarti terdapat pengaruh yang signifikan antara variabel- variabel independen terhadap variabel dependen secara simultan.

2) Menentukan tingkat signfikansi yaitu sebesar $0,05(\alpha=0,05)$ Membandingkan $\mathrm{F}$ hitung dengan $\mathrm{F}$ table.

c. Uji Parsial atau Uji $\mathrm{t}$

Uji parsial atau uji $\mathrm{t}$ dimaksudkan untuk mengetahui apakah variabel bebas secara sendiri-sendiri (parsial) berpengaruh nyata (signifikan) terhadap variabel terikat. Pada uji ini hipotesis satu sampai dengan lima atau H1 sampai dengan H5 di uji dengan menggunakan uji t. Pengujian dapat dilakukan dengan cara sebagai berikut Ghozali (2016) :

1) Menyusun Hipotesis nol (H0) dan Hipotesis alternative $(\mathrm{H} 1)$

Ho : $\beta 1=\beta 2=\beta 3=\beta 4=\beta 5=0$, variabel independen secara parsial tidak berpengaruh signifikan terhadap variabel dependen.

2) Menentukan tingkat signifikansi ( $\alpha)$ sebesar 0,05 
Jurnal Akuntansi \& Perpajakan, Volume 2, No. 2, Januari 2021

H1 akan diterima jika nilai probabilitasnya kurang dari $0,05(\alpha)$.

\section{HASIL DAN PEMBAHASAN}

\begin{tabular}{|l|c|c|c|c|c|}
\hline & Descriptive Statistics \\
\hline \hline Log_Harga & 80 & 1,892 & 4,124 & 2,967 & 0,677 \\
CAR & 80 & 0,127 & 0,238 & 0,171 & 0,024 \\
LDR & 80 & 0,558 & 1,089 & 0,858 & 0,104 \\
NIM & 80 & 0,019 & 0,101 & 0,053 & 0,016 \\
NPL & 80 & 0,002 & 0,039 & 0,013 & 0,009 \\
BOPO & 80 & 0,599 & 0,989 & 0,796 & 0,135 \\
Valid N (listwise) & 80 & & & & \\
\hline
\end{tabular}

\section{Harga Saham}

Harga saham tertinggi dan terendah terjadi pada 2015, yaitu harga saham tertinggi sebesar log-4,1239 atau Rp13.300,- adalah saham BBCA (PT. Bank Central Asia Tbk) dan harga saham terendah log-1,8921 atau Rp.78,- adalah saham INPC (PT. Bank Artha Graha Internasional Tbk). Kecenderungan harga saham tertinggi mengalami peningkatan dari Rp9.100,- pada 2012 menjadi Rp.13.100,- pada 2015. Sedangkan kecenderungan harga saham dengan nilai terendah mengalami penurunan adalah dari nilai Rp 111,- pada tahun 2012 menjadi Rp78,pada tahun 2015 .

\section{Capital Adequacy Ratio (CAR)}

BTPN (PT. Bank Tabungan Pensiunan Nasional Tbk.) memiliki CAR tertinggi sebesar 0,2380 (23,80\%) pada 2015. Sedangkan BNII (PT. Bank Maybank Indonesia Tbk) mempunyai CAR terendah sebesar $0,1274(12,74 \%)$ pada 2013. Kecenderungan CAR baik yang tertinggi dan terendah terus mengalami peningkatan. Secara umum nilai CAR bank yang menjadi sampel penelitian di atas ketentuan yang berlaku minimal sebesar $12 \%$.

\section{Loan to Deposit Ratio (LDR)}

BBTN (PT. Bank Tabungan Negara Tbk.) memiliki LDR tertinggi sebesar 1,0886 (108,86\%) pada 2014. Sedangkan BACA (PT. Bank Capital Indonesia Tbk.) mempunyai LDR terendah sebesar 0,5578 (55,78\%) pada 2015. Kecenderungan LDR baik yang tertinggi dan terendah mengalami penurunan. LDR merupakan salah komponen penilaian kesehatan bank, di mana besaran kategori bank sehat dari aspek penyaluran kredit (loan) atau LDR adalah $80 \%$ - 100\%. Deskripsi data penelitian terdapat 1 bank yang memiliki LDR yaitu BBTN (PT.Bank Tabungan Negara Tbk.) selama periode 2012 sampai dengan 2015. Sedangkan bank memiliki LDR di bawah $80 \%$ sebanyak 8 bank pada 2012, tetapi pada 2015 mengalami penurunan menjadi hanya 3 bank. Artinya terdapat perbaikan atau peningkatan dana masyarakat yang disalurkan dalam kredit.

\section{Net Interest Margin (NIM)}

BDMN (PT. Bank Danamon Tbk.) memiliki NIM tertinggi sebesar 0,1010 (10,10\%) pada 2012. Sedangkan BTPN (PT. Bank Tabungan Pensiunan Nasional Tbk.) mempunyai NIM terendah sebesar $0,0188(1,88 \%)$ pada 2014. Kecenderungan NIM baik yang tertinggi dan terendah mengalami penurunan. Artinya 
Jurnal Akuntansi \& Perpajakan, Volume 2, No. 2, Januari 2021

kemampuan aset bank untuk menghasilkan interest margin mengalami penurunan.

\section{Non-Performing Loan (NPL)}

BVIC (PT. Bank Victoria Internasional Tbk.) memiliki NIM tertinggi sebesar 0,0393 (3,93\%) pada 2015. Sedangkan BACA (PT. Bank Capital Indonesia Tbk.) mempunyai NIM terendah sebesar 0,019 (1,90\%) pada 2013. Kecenderungan NPL tertinggi berfluktuasi dan cenderung naik, sedangkan NPL dan terendah cenderung tidak mengalami perubahan.

\section{Biaya Operasional dan Pendapatan Operasional (BOPO)}

BNLI (PT. Bank Permata Tbk.) memiliki BOPO tertinggi sebesar 0,9890 (98,90\%) pada 2015. Sedangkan BBRI (PT. Bank Rakyat Indonesia Tbk.) mempunyai BOPO terendah sebesar $0,599 \quad(59,99 \%)$ pada 2012. Kecenderungan BOPO tertinggi berfluktuasi dan cenderung naik, sedangkan BOPO dan terendah cenderung naik.

\section{Uji Normalitas Data}

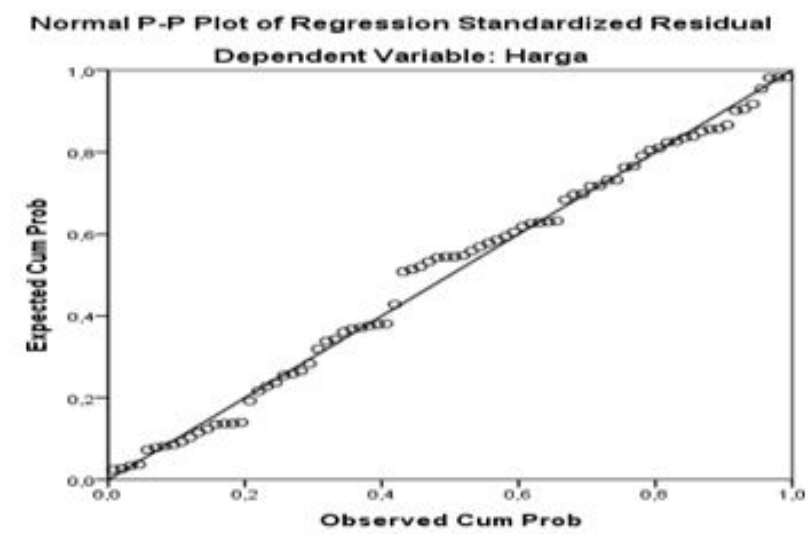

Uji normalitas data dalam penelitian dilakukan secara grafis atau scatterplot sebaran dari nilai residual. Hasilnya diketahui bahwa nilai residual data penelitian tersebar atau terletak pada garis diagomal. Hipotesis menyatakan bahwa jika sebaran nilai residual data penelitian terletak pada sekitar garis diagonal dapat disimpulkan data memiliki distribusi normal.

\section{Uji Multikolinearitas}

\begin{tabular}{|l|r|r|}
\hline \multicolumn{2}{|c|}{ Coefficients $^{\mathbf{a}}$} \\
\cline { 2 - 3 } \multicolumn{1}{|c|}{ Model } & \multicolumn{1}{|c|}{ Collinearity Statistics } \\
\hline \hline CAR & 0,898 & \multicolumn{1}{c|}{ VIF } \\
LDR & 0,983 & 1,113 \\
NIM & 0,964 & 1,017 \\
NPL & 0,813 & 1,038 \\
BOPO & 0,741 & 1,229 \\
\end{tabular}

a. Dependent Variable: Log_Harga

Dari data tabel 4.2. dapat diketahui bahwa nilai Tolerance di atas 0,10 dan nilai VIF di bawah 10 dari masing-masing variabel bebas model regresi yang terbentuk. Hal ini dapat disimpulkan bahwa model regresi yang dibangun terbebas dari gejala multikolinieritas.

\section{Uji Heterokedastisitas}

\begin{tabular}{|c|c|c|c|c|c|}
\multicolumn{7}{|c|}{ Coefficients $^{\mathbf{a}}$} \\
\hline \multirow{2}{*}{ Model } & \multicolumn{2}{|c|}{ Unstand ardized Coefficients } & $\begin{array}{c}\text { Standarized } \\
\text { Coefficients }\end{array}$ & \multirow{2}{*}{ t } & \multirow{2}{*}{ Sig. } \\
\cline { 2 - 4 } & B & Std. Error & Beta & & \\
\hline \hline (Constant) & 0,341 & 0,345 & & 0,988 & 0,236 \\
CAR & 2,243 & 1,128 & 0,299 & 1,990 & 0,050 \\
LDR & $-0,221$ & 0,195 & $-0,125$ & $-1,132$ & 0,261 \\
NIM & $-2,580$ & 1,694 & $-0,169$ & $-1,523$ & 0,132 \\
NPL & $-2,975$ & 3,207 & $-0,112$ & $-0,928$ & 0,356 \\
BOPO & $-0,031$ & 0,223 & $-0,018$ & $-0,139$ & 0,890 \\
\hline
\end{tabular}

Diketahui bahwa nilai signifikansi thitung untuk variabel bebas CAR sebesar 0,050 sama dengan alpha sebesar 0,05 sedangkan nilai 
Jurnal Akuntansi \& Perpajakan, Volume 2, No. 2, Januari 2021

signifikansi dari thitung untuk variabel bebas lainnya lebih besar dari 0,05 . Dari nilai signifikansi thitung dari masing-masing variabel bebas tersebut dapat disimpulkan model yang dihasilkan terbebas dari gejala heteroskedastitas atau sesuai dengan uji secara grafis.

\section{Uji Autokorelasi}

\begin{tabular}{|l|r|r|r|r|r|}
\hline Model & \multicolumn{1}{|c|}{ Model Summary } \\
\end{tabular}

Dengan membandingkan nilai kritis dL dan dU serta 4-dL dan 4-dU dapat digambarkan posisi nilai DW hasil komputasi sebagaimana terlihat pada Gambar 4.3

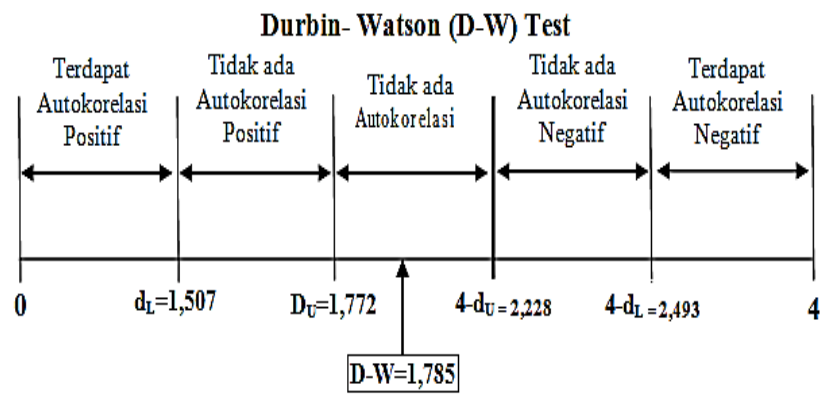

Oleh karena nilai DW berada di antara du $(1,772)$ dan 4-du (2,228), maka hipotesis H0 diterima dan H1 ditolak. Artinya data penelitian yang digunakan tidak terdapat gejala autokorelasi yang positif maupun negatif.

\section{Uji Hipotesis}

\section{Uji Ketepatan Model (Goodness of Fit)}

\begin{tabular}{|ll|c|c|c|c|c|}
\hline \multicolumn{1}{|c|}{ ANOVAa $^{\text {Model }}$} & $\begin{array}{c}\text { Sum of } \\
\text { Squares }\end{array}$ & df & Mean Square & F & Sig. \\
\hline \hline 1 & Regression & 23,529 & 5 & 4,706 & 27,577 & $0,000^{\mathrm{b}}$ \\
& Residual & 12,627 & 74 & 0,171 & & \\
Total & 36,156 & 79 & & & \\
\hline
\end{tabular}

a. Dependent Variable:Log Harga

b. Predictors: (Constant), BOPO, LDR, NM, CAR, NPL
Dapat diketahui nilai koefisien determinasi (R2) dan nilai koefisien determinasi yang disesuaikan (adjusted R2) masing-masing sebesar 0,651 dan 0,627. Artinya kemampuan variabel bebas menjelaskan variasi variabel terikat sebesar 0,627 atau $62,70 \%$ dan sisanya sebesar 37,30 dijelaskan atau dipengaruhi variabel lain di luar variabel penelitian ini.

\section{Uji Parsial (Uji t)}

\begin{tabular}{|c|c|c|c|c|c|c|}
\hline & \multicolumn{6}{|c|}{ Coefficients $^{\mathrm{a}}$} \\
\hline & \multirow{2}{*}{ Model } & \multicolumn{2}{|c|}{ Unstandardized Coefficients } & \multirow{2}{*}{$\begin{array}{c}\text { Standarized } \\
\text { Coefficients } \\
\text { Beta } \\
\end{array}$} & \multirow{2}{*}{$\mathrm{t}$} & \multirow{2}{*}{$\begin{array}{c}\text { Sig. } \\
\text { (One } \text { TaIled) }\end{array}$} \\
\hline & & B & Std. Error & & & \\
\hline \multirow[t]{6}{*}{1} & (Constant) & 3,117 & 0,689 & & 4,527 & 0,000 \\
\hline & CAR & 0,536 & 2,204 & $-0,019$ & $-0,265$ & 0,396 \\
\hline & LDR & 1,961 & 0,452 & 0,301 & 4,343 & 0,000 \\
\hline & NMM & 12,598 & 3,306 & 0,290 & 4,149 & 0,000 \\
\hline & NPL & $-18,110$ & 5,574 & $-0,240$ & $-3,147$ & 0,001 \\
\hline & BOPO & $-2,734$ & 0,401 & $-0,544$ & $-6,818$ & 0,000 \\
\hline
\end{tabular}

Dari hasil diatas maka CAR tidak berpengaruh positif terhadap variabel terikat harga saham perbankan yang tercatat di BEI dengan tingkat kepercayaan sebesar 95\% atau tingkat kesalahan sebesar 5\%.

Berdasarkan tanda koefisien regresi LDR positif (+) dan nilai signifikansi thitung LDR sebesar 0,000 lebih kecil dari alpha sebesar 0,05 artinya LDR berpengaruh positif dan signifikan terhadap harga saham perbankan yang tercatat di BEI.

Berdasarkan tanda koefisien regresi NIM positif (+) dan nilai signifikansi thitung NIM sebesar 0,000 lebih kecil dari alpha sebesar 0,05 artinya NIM berpengaruh positif dan signifikan terhadap harga saham perbankan yang tercatat di BEI.

Berdasarkan tanda koefisien regresi NPL negatif (-) dan nilai signifikansi thitung NPL sebesar 0,001 lebih kecil dari alpha sebesar 0,05 artinya 
Jurnal Akuntansi \& Perpajakan, Volume 2, No. 2, Januari 2021

NPL berpengaruh negatif dan signifikan terhadap harga saham perbankan yang tercatat di BEI.

Berdasarkan tanda koefisien regresi NPL negatif (-) dan nilai signifikansi thitung BOPO sebesar 0,000 lebih kecil dari alpha sebesar 0,05 artinya BOPO berpengaruh negatif dan signifikan terhadap harga saham perbankan yang tercatat di BEI.

\section{PENUTUP}

Kesimpulan

Dari analisis dan pengujian hipotesis data penelitian ditemukan hasil sebagai berikut:

a. CAR tidak berpengaruh Positif terhadap harga saham bank yang tercatat di Bursa Efek Indonesia.

b. NIM berpengaruh positif terhadap harga saham bank yang tercatat di Bursa Efek Indonesia.

c. LDR berpengaruh positif terhadap harga saham bank yang tercatat di Bursa Efek Indonesia.

d. NPL berpengaruh negatif terhadap harga saham bank yang tercatat di Bursa Efek Indonesia.

e. BOPO berpengaruh negatif terhadap harga saham bank yang tercatat di Bursa Efek Indonesia.

\section{Saran}

a. Bagi Manajemen Bank
Secara statistik diperoleh hasil penelitian bahwa CAR tidak berpengaruh signifikan terhadap harga saham bank, tetapi secara operasional variabel CAR merupakan variabel utama dan variabel yang harus diperhatikan oleh manajemen bank. Oleh karena itu peneliti menyarankan kepada manajemen bank agar memperhatikan variabel tersebut agar meningkatkan nilai saham.

b. Investor Pasar Modal

Kepada investor agar dapat mempertimbangkan variabel yang diteliti tersebut sebagai dasar pengambilan keputusan untuk beli/ jual saham bank untuk memaksimalkan hasil (return) karena perubahan harga (price appreciation) yang merupakan imbal komponen utama dari imbal hasil saham.

c. Bagi Akademisi dan Bagi Penelitian Berikut.

Bagi akademi dan penelitian berikutnya dapat menggunakan sampel yang lebih banyak dan periode waktu yang lebih panjang agar semakin mendekati hasil analisa yang diharapkan. Disamping itu teknik analisis data dapat menggunakan data panel agar perbedaan periode waktu dari setiap sampel penelitian dapat diatasi. 
Jurnal Akuntansi \& Perpajakan, Volume 2, No. 2, Januari 2021

\section{DAFTAR PUSTAKA}

Ali, Masyhud. 2004. Asset Liability Management: Menyiasati Risiko Pasar Bandarlampung”. Jurnal Ekonomi \& Bisnis, No. 3, Jilid 8 dan Risiko Operasional. PT.Gramedia. Jakarta.

Almilia, L.S. dan Winny Herdiningtyas. 2005. Analisis Rasio CAMEL terhadap Prediksi Kondisi Bermasalah pada Lembaga Perbankan Periode 20002002. Jurnal Akuntansi dan Keuangan, Vol.7, No.2, November: 131- 147.

Bank Indonesia. 2004. Surat Edaran Bank Indonesia Nomor: 6/10/PBI/2004.

Jakarta.

Bank Indonesia. 2011. Peraturan Bank Indonesia Nomor 13/1/PBI/2011 Tentang Penilaian Tingkat Kesehatan Bank Umum. Jakarta.

Bank Indonesia. 2011. Surat Edaran Bank Indonesia Nomor 13/24/DPNP Perihal Penilaian Tingkat Kesehatan Bank Umum. Jakarta.

Basir, S. dan Fakhruddin, H. M., 2005. Aksi Korporasi. Jakarta: Salemba Empat.

Bodie, Z., Kane A., dan Marcus, A. J., 2014. Manajemen Portofolio dan Investasi, Edisi 9 Buku 2. Jakarta:Salemba Empat.

Butarbutar, Jekson. 2014. Analisis pengaruh Rasio keuangan terhadap harga saham melalui Kinerja perusahaan. Jakarta.

Darmadji, T. \& Fakhruddin, H .M. 2011. Pasar Modal di Indonesia pendekatan dan tanya jawab. Edisi ke-3. Jakarta : Salemba Empat.

Dendawijaya. 2009. Manajemen Perbankan. Jakarta. Ghalia Indonesia.

Dianasari, Novita. 2013. Pengaruh CAR, ROE, LDR dan NPL Terhadap Return Saham Serta Pengaruh
Saat Sebelum dan Sesudah Publikasi Laporan Keuangan Pada Bank Go Public di Bursa Efek Indonesia. Bekasi.

Domiyanti, Samita. 2012. Analisis Pengaruh Kinerja Keuangan Terhadap Harga Saham Yang Terdaftar Di BEI. Medan.

Ghozali, Imam. 2016. Aplikasi Analisis Multivariate dengan Program IBM SPSS 20 Edisi 6. Badan Penerbit Universitas Diponegoro Semarang

Gitman,L. J. dan Zutter, C. J., 2013. Principles of Managerial Finance 13th Edition. Global Edition: Pearson Eduaction Limited.

Gujarati, D.N. 2010. Dasar-dasar Ekonometrika. Terjemahan Mangunsong, R.C. Salemba Empat. Buku 2. Jakarta

Hasibuan. P. Malayu. 2007. Dasar-dasar Perbankan. Bumi Aksara. Jakarta. Hartono, J., 2014. Teori Portofolio dan Analisis Investasi, Edisi 8, Cetakan Pertama. Yogyakarta:BPFE.

Idroes, Ferry. 2008. Manajemen Resiko Perbankan. Jakarta.

Indra Satria dan Iha Haryani Hatta. 2015. Pengaruh Kinerja Keuangan terhadap Harga Saham 10 Bank Terkemuka Di Indonesia. Jakarta.

Kasmir. 2014. Bank dan Lembaga Keuangan Lainnya. Edisi Revisi, Cetakan keempatbelas, PT. Raja Grafindo Persada, Jakarta.

Kurniadi, Rintistya. 2012. Pengaruh CAR, NIM, LDR terhadap Return Saham Perusahaan Perbankan Indonesia. Accounting Analysis Journal 1 (1). Volume 1 nomor 1, halaman 9. Jakarta

Mahardian, Pandu. 2008. Analisis Pengaruh Rasio CAR, BOPO, NPL, NIM, dan LDR terhadap Kinerja 
Jurnal Akuntansi \& Perpajakan, Volume 2, No. 2, Januari 2021

Keuangan Perbankan. Tesis. Universitas Diponegoro. Semarang.

Maksum. 2013. Analisis Pengaruh Kinerja Keuangan terhadap Harga Saham Pada Lembaga Keuangan Perbankan di BEI. Skripsi. Universitas Tanjung Pura. Jakarta.

Maria Ulfa dan Budiyanto. 2014. Pengaruh Kinerja Keuangan Terhadap Harga Saham Bank Umum Milik Pemerintah Di BEI. Jurnal Ilmu dan Riset Manajemen Vol. 3 No. 11. Surabaya

Nia Arwita br G. 2013. Pengaruh CAR, NPL, BOPO, dan LDR Terhadap Pertumbuhan Laba Pada Perusahaan Perbankan Yang Terdaftar Di Bursa Efek Indonesia. Medan.

Peraturan Bank Indonesia Nomor 10/15/PBI/2008. Kewajiban Penyediaan Modal Minimum Bank Umum. Jakarta

Peraturan Bank Indonesia Nomor: 06/10/PBI/2004. 2004. Sistem Penilaian Tingkat Kesehatan Bank Umum. Jakarta.

Peraturan Bank Indonesia Nomor: 15/15/PBI/2013. 2013. Giro Wajib Minimum Bank Umum Dalam Rupiah dan Valuta Asing bagi Bank Umum Konvensial. Jakarta

Prasnanugraha. P, Ponttie. 2007. Analisis Pengaruh Rasio-rasio Keuangan terhadap Kinerja Bank Umum Di Indonesia (studi empiris Bank-bank Umum yang beroperasi Di Indonesia). Jakarta

Reilly, Frank. dan Brown, Keith. 2012. Investment Analysis and Portofolio Management. 10th Edition. Mason-Ohio: South-Western Cengage Learning.

Rosita, Muharam, dan Haryanto 2015. Analisis Pengaruh Tingkat Kesehatan Bank Dengan Metode Camels Terhadap Return Saham (Studi Kasus Pada Bank Listed Di Bei Periode 2008-2014). Semarang.
Samoedra, A. D. A., dan Susanti, N., 2014. The Effect Of Return On Asset (ROA), Return On Equity (ROE), and Net Profit Margin (NPM) On Stock Price On Food and Beverages Companies Listed In Indonesia Stock Exchange (IDX). Bandung:Widyatama University.

Siamat, Dahlan. 1993. Manajemen Bank Umum. Jakarta. Intermedia.

Sinkey JR, Joseph F. 2002. Commercial Bank Financial Management: In The Financial Services Industry. Sixth Edition. Prentice Hall.

Sunariyah, 2004. Pengantar Pengetahuan Pasar Modal. Yogyakarta: UPP AMP YKPN.

Tandelilin, E., 2010. Analisis Investasi dan Manajemen Portofolio, Edisi Pertama. Yogyakarta: Kanisius.

Totok Budisantoso dan Sigit Triandaru. 2006. Bank dan Lembaga Keuangan Lain. Salemba Empat. Jakarta.

Undang-undang Republik Indonesia Nomor 10 tahun 1998. Tentang perubahan atas undang-undang Nomor 7 tahun 1992 tentang perbankan.

Wismaryanto, Sigit Dwi. 2013. Pengaruh NPL, LDR, ROA, ROE, NIM, BOPO, Dan CAR Terhadap Harga Saham Pada Sub Sektor Perbankan Yang Terdaftar Di Bursa Efek Indonesia Tahun 2008 2012. Yogyakarta.

Yulimel Sari. 2013. Pengaruh Profitabilitas, kecukupan modal, dan likuiditas terhadap harga saham. Padang.

www.bi.go.id www.idx.co.id 